\title{
ANALISIS TINGKAT KERENTANAN BANJIR DENGAN PENDEKATAN GEOEKOSISTEM DI SUB DAS BABURA PROVINSI SUMATERA UTARA
}

Oleh :

\author{
Anik Juli Dwi Astuti, Meilinda Suriani, dan Julismin*
}

\begin{abstract}
Abstrak
Penelitian ini bertujuan untuk mengetahui agihan tingkat kerentaan banjir dan karakteristik kerentanan banjir di subDAS Babura, merumuskan strategi pengelolaan lingkungan untuk menanggulangi daerah-daerah yang rentan terhadap banjir. Untuk mencapai tujuan penelitian maka dalam pelaksanaan penelitian ini digunakan beberapa metode survei, yaitu survei instansional dan survei lapangan. Survei instansional digunakan untuk mengumpulkan data sekunder yang meliputi data curah hujan, bentuk lahan dan penggunaan lahan. Survei lapangan digunakan untuk mendapatkan data tekstur tanah, kondisi banjir sebenarnya, dan informasi penggunaan lahan. Survei lapangan juga dilakukan dengan observasi dan wawancara bebas terhadap narasumber yang tinggal di sekitar sungai Babura. Teknik pengolahan data dilakukan dengan metode skoring pada parameter-parameter kerentanan banjir.

Data yang dikumpulkan dalam penelitian ini adalah data Primer, terdiri dari tekstur tanah, kemiringan lereng, kondisi banjir sebenarnya,dan penggunaan lahan. Data Sekunder, terdiri dari data curah hujan, bentuklahan dan penggunaan lahan. Hasil penelitian dianalisis secara mendalam dengan menggunakan analisis deskriptif dan analisis spasial (keruangan). Hasil akhir penelitian ini adalah Peta kerentanan Banjir di subDAS Babura dimana kerentanan banjir di sub DAS Babura dibagi menjadi tiga kelas, yaitu tidak rentan $(15,98 \%)$, cukup rentan $(43,14 \%)$, dan rentan $(40,97 \%)$. Daerah yang tidak rentan terhadap banjir meliputi hulu sungai Babura yang terdiri dari Kecamatan Sibolangit dan sebagian Kecamatan Pancurbatu. Daerah yang cukup rentan terhadap banjir mencakup daerah tengah sub DAS babura terdiri dari sebagian Kecamatan Pancurbatu dan Kecamatan Namorambe. Daerah yang rentan terhadap banjir meliputi daerah hilir sungai Babura meliputi Kecamatan Medan Petisah, Polonia, Medan Selayang, Medan Johor, dan Medan Tuntungan. Strategi pengelolaan lingkungan untuk menanggulangi daerah yang rentan terhadap banjir adalah berprinsip pada pengelolaan lingkungan DAS yang harus berpegang pada one river and one management yang meliputi kegiatan perencanaan, penataan, penetapan, pemanfaatan, pelestarian, pengawasan dan pemantauan dengan melibatkan tiga unsur kelembagaan (Pemerintah, masyarakat dan swasta)
\end{abstract}

\section{Kata Kunci : Kerentanan, Banjir, Geoekosistem}

\section{A. Pendahuluan}

\footnotetext{
${ }^{*}$ Dosen Jurusan Pendidikan Geografi, Fakultas Ilmu Sosial, UNIMED
} 
Daerah Aliran Sungai adalah suatu daerah yang dibatasi oleh pemisah topografi yang menerima, mengumpulkan air hujan, sedimen, dan unsur hara serta mengalirkannya melalui anak-anak sungai dan keluar pada satu outlet. Sebagai penerima, pengumpul, dan penyalur air, kondisi Daerah Aliran Sungai memiliki peranan penting bagi keberlangsungan daur hidrologi yang ada didalamnya maupun proses-proses yang terkait dengan air hujan. Sub Daerah Aliran Sungai Babura secara administratif mencakup sebagian kecil dari Kabupaten Deli Serdang dan kota Medan. DAS Babura mempunyai luas $\pm 4921,88$ Ha yang terbentang dari hulu yaitu Kecamatan Sibolangit Deli Serdang hingga outletnya yaitu Medan Sunggal.

Kota Medan yang merupakan bagian dari subDAS Babura adalah ibukota Provinsi Sumatera Utara yang mempunyai berbagai macam potensi baik ditinjau dari potensi fisik maupun sosialekonomi. Ditinjau dari segi potensi fisik, Sebagian Kota Medan mempunyai potensi sumber daya air yang cukup besar berupa air permukaan, dan airtanah. Kondisi hidrologi sebagian Kota Medan sangat dipengaruhi oleh sub Daerah Aliran Sungai Babura dimana sebagian wilayah Kota Medan termasuk dalam system DAS tersebut. Sebagian dari kota Medan termasuk bagian hilir dari subDAS Babura yang umumnya digunakan sebagai daerah pemanfaatan (discharge area) sehingga potensi sumber daya airnya sangat tergantung pada daerah hulu (Kecamatan Sibolangit, Kabupten Deli Serdang). Daerah hulu tersebutlah yang berfungsi utama sebagai daerah tangkapan air (recharge area) sehingga kondisi fisik daerah hulu sangat berpengaruh terhadap limpahan air yang akan diterima di daerah hilir, yaitu Kota Medan.

SubDAS Babura yang merupakan bagian dari DAS Deli di bagian hulu mempunyai topografi berupa perbukitan dan semakin ke hilir bertopografi dataran. Sungai utama yang mengalir di subDAS Babura adalah Sungai Babura yang merupakan cabang dari Sungai Deli. Sungai Babura menyediakan potensi air yang besar dan memberikan manfaat bagi masyarakat terutama Kota Medan, namun seringkali juga mendatangkan bencana, yaitu banjir yang setiap tahun terjadi. Banjir yang terjadi di Kota Medan salah satu kemungkinannya diakibatkan oleh adanya perubahan tataguna lahan di daerah hulu kawasan DAS, kesalahan dalam mengimplementasikan rencana tata ruang Kota Medan, maupun iklim ekstrim yang terjadi akhir-akhir ini. Banjir yang terjadi menyebabkan kerugian-kerugian baik berupa harta benda yang tidak sedikit maupun kerugian jiwa.

Banjir besar yang terjadi di Kota Medan pada Januari 2011 mencapai tinggi 1,5 - 2 meter merendam ratusan rumah di 10 
Kecamatan di Kota Medan. Pada bulan April 2011 ketinggian banjir mencapai 2 meter dan merendam ratusan rumah. Selain rumah, berbagai macam infrastruktur pengairan, jalan dan fasilitas umum menjadi ancaman yang serius bagi kelangsungan pembangunan di daerah ini. Berbagai macam aktifitas terhenti sehingga mempengaruhi kelangsungan pembangunan yang ada di daerah yang terkena banjir. Analisis kerentanan banjir menjadi sangat perlu dilakukan untuk mengetahui daerah-daerah yang rawan terjadi banjir sehingga dapat menentukan strategi pengelolaan yang tepat untuk pencegahan dan penanggulangan banjir.

Berdasarkan latar belakang dapat dirumuskan permasalahan penelitian sebagai berikut: 1) Bagaimana agihan tingkat kerentanan banjir dan karakteristik kerentanan banjir di daerah penelitian. 2) Bagaimana strategi pengelolaan lingkungan untuk daerah-daerah yang rentan terhadap banjir. Dengan demikian, tujuan penelitian ini dapat dirumuskan sebagai berikut: 1) Mengetahui agihan tingkat kerentaan banjir dan karakteristik kerentanan banjir di daerah penelitian. 2) Merumuskan strategi pengelolaan lingkungan untuk daerah-daerah yang rentan terhadap banjir.

\section{B. Metode Penelitian}

Penelitian ini dilakukan di sub Daerah Aliran Sungai Babura Provinsi Sumatera Utara. Penelitian ini menggunakan metode Survei. Survei yang dilakukan adalah survei instansional maupun survei lapangan. Survei instansional dilakukan dengan mengumpulkan data-data dari berbagai instansi, dokumen atau arsip, dan studi kepustakaan. Survei lapangan dilakukan dengan pengukuran langsung di lapangan melalui observasi maupun wawancara bebas. Alat dan bahan yang diperlukan untuk melakukan penelitian ini meliputi:

a. GPS, digunakan untuk penentuan lokasi sampel di daerah penelitian.

b. Peta Rupa Bumi Indonesia, digunakan sebagai peta dasar untuk pembuatan Peta Tematik lainnya.

c. Peta Geologi, digunakan untuk interpretasi kondisi geologi di daerah penelitian.

d. Citra Penginderaan Jauh, untuk interpretasi penggunaan lahan

e. Kamera, digunakan untuk dokumentasi pada saat dilakukan survei lapangan.

f. Seperangkat komputer dilengkapi dengan software Arc.View 3.3. digunakan untuk pengolahan data berbasis sistem informasi geografi. 
g. Alat tulis yang berguna dalam pelaksanaan penelitian.

Data yang diukur dan dikumpulkan dalam penelitian ini antaralain:

a. Data Primer, terdiri dari tekstur tanah, kemiringan lereng, kondisi banjir sebenarnya, penggunaan lahan.

b. Data Sekunder, terdiri dari data curah hujan, bentuklahan dan penggunaan lahan.

Pengolahan data dilakukan dengan tumpangsusun/overlay parameter-parameter banjir berjenjang tertimbang dengan menggunakan Sistem Informasi Geografis (SIG). Overlay dilakukan dengan input empat peta tematik, yaitu ; Peta Curah hujan, Peta Kemiringan Lereng, Peta tekstur Tanah, dan Peta Penggunaan Lahan, dimana keempat peta tersebut merupakan parameter-parameter kerentanan banjir dalam penelitian ini. Sebagian besar parameter-parameter kerentanan banjir berupa data spasial yang bersifat kualitatif, untuk melakukan proses analisis, masing-masing parameter perlu ditransformasikan kedalam bentuk kuantitatif dalam bentuk pengharkatan dan pembobotan. Prosedur pemberian harkat dan bobot mengacu pada penelitian-penelitian sebelumnya. Pemberian bobot pada masingmasing parameter atau variable berbeda-beda, yaitu dengan memperhatikan seberapa besar pengaruh parameter-parameter tersebut terhadap terjadinya banjir. Semakin besar pengaruh parameter tersebut terhadap banjir maka nilai bobotnya juga besar, sebaliknya jika pengaruhnya kecil maka nilai bobotnya juga kecil.

\begin{tabular}{|c|l|c|}
\multicolumn{3}{|c}{ Klasifikasi Tingkat Kerentanan Banjir } \\
\hline No & Tingkat Kerentanan & Skor \\
\hline 1 & Sangat Tidak Rentan & $10-18$ \\
\hline 2 & Tidak Rentan & $>18-26$ \\
\hline 3 & Cukup Rentan & $>26-34$ \\
\hline 4 & Rentan & $>34-42$ \\
\hline 5 & Sangat Rentan & $>42-50$ \\
\hline
\end{tabular}

Sumber : Pengolahan Data

Penelitian ini menggunakan beberapa analisis agar hasil yang diperoleh sesuai dengan yang diharapkan. Analisis yang digunakan antaralain: analisis spasial yang digunakan untuk menjelaskan secara keruangan agihan kerentanan banjir yang terjadi di sub DAS Babura. Analisis deskriptif yang digunakan untuk menjelaskan pola sebaran banjir dan karakteristik kerentanan banjir. Selain itu, analisis deskriptif juga digunakan untuk menjelaskan kondisi fisik, dan sosial di sub DAS Babura 
serta strategi pengelolaan lingkungan untuk penanganan daerahdaerah yang rentan terhadap banjir.

\section{Hasil Dan Pembahasan}

Sub DAS Babura merupakan bagian dari DAS Deli dengan sungai utama yang mengalir di daerah penelitian adalah sungai Babura. Sungai Babura mempunyai anak-anak sungai kecil yang terletak di daerah hulu. Pada musim kemarau dimana curah hujan mengecil, debit sungai menjadi berkurang, sebaliknya pada musim penghujan debitnya menjadi besar bahkan menimbulkan banjir. Hal ini menunjukan bahwa sungai Babura ditinjau dari kontinuitas alirannya termasuk sungai intermitten. Selain berasal dari air hujan, sungai yang ada di DAS Babura juga mendapatkan pasokan air dari mata air (Springs) dan rembesan (Seepage), sehingga pada musim kemarau sungai Babura masih mampu mengalirkan air walaupun dengan debit yang lebih kecil.

Sub Daerah Aliran Sungai Babura secara administratif mencakup dua Kabupaten/kota, yaitu: Kabupaten Deli Serdang, dan Kota Medan. Berdasarkan Peta Rupa Bumi Indonesia Lembar Medan, Sub Daerah Aliran Sungai Babura terletak antara 3'21' $3^{\circ} 35^{\prime}$ LU dan $98^{\circ} 35^{\prime}$ - 98 $41^{\prime}$ ' BT. Berdasarkan analisis Peta Rupa Bumi Indonesia, luas total sub DAS Babura $\pm 4.921,88$ ha. Luasan total pada masing-masing kecamatan yang tercakup di subDAS Babura adalah sebagai berikut

\begin{tabular}{|l|r|r|}
\hline \multicolumn{1}{|c|}{ Kecamatan } & Luas Wilayah (Ha) & Persentase (\%) \\
\hline Kec. Sibolangit & 210,00 & 4,27 \\
\hline Kec. Pancurbatu & $1.136,65$ & 23,09 \\
\hline Kec. Namorambe & $1.792,67$ & 36,42 \\
\hline Kec. Medan Petisah & 0,88 & 0,02 \\
\hline Kec. Medan Polonia & 592,31 & 12,03 \\
\hline Kec. Medan Maimun & 2,97 & 0,06 \\
\hline Kec. Medan Sunggal & 192,83 & 3,92 \\
\hline Kec. Medan Selayang & 14,24 & 0,29 \\
\hline Kec. Medan Johor & 823,97 & 16,74 \\
\hline Kec. Medan Tuntungan & 155,35 & 3,16 \\
\hline Total Luas & $4.921,88$ & 100,00 \\
\hline
\end{tabular}

Sumber : Analisis Peta Administrasi, 2012

\section{Tingkat Kerentanan Banjir}

Banjir terjadi karena adanya luapan air sungai yang diakibatkan oleh ketidakmampuan sungai dalam menampung air 
dimana debit sungai yang mengalir pada saluran sungai tersebut melebihi daya tampung sungai yang terjadi pada keadaan curah hujan yang tinggi. Kerentanan banjir menggambarkan mudah atau tidaknya suatu daerah terkena banjir dengan mendasarkan pada beberapa faktor tertentu dimana pada penelitian ini didasarkan pada curah hujan, penggunaan lahan, kemiringan lereng dan tekstur tanah.

Berdasarkan hasil overlay dan analisis faktor-faktor penentu kerentanan banjir didapatkan peta kerentanan banjir. Dengan melihat Peta Kerentanan Banjir dapat diketahui bahwa sub DAS Babura dibagi menjadi tiga klasifikasi kerentanan banjir, yaitu tidak rentan, cukup rentan dan rentan. Tabel menunjukkan luas masing-masing tingkat kerentanan banjir di sub DAS Babura.

\begin{tabular}{|c|l|r|r|}
\hline No & Kelas Kerentanan Banjir & \multicolumn{1}{c|}{ Luas (Ha) } & Persen Luas (\%) \\
\hline 1 & Rentan & $2.016,60$ & 40,97 \\
\hline 2 & Cukup Rentan & $2.123,30$ & 43,14 \\
\hline 3 & Tidak Rentan & 781,98 & 15,89 \\
\hline \multicolumn{2}{|c|}{ Total luas } & $4.921,88$ & 100,00 \\
\hline
\end{tabular}

Sumber : Analisis Peta Curah Hujan, Peta Penggunaan Lahan, Peta

Lereng, dan Peta Tanah, Tahun 2012

Daerah rentan banjir di sub DAS Babura mempunyai luas 2.016 Ha $(40,97 \%)$ dari total luas sub DAS Babura tersebut. Daerah rentan banjir di sub DAS Babura mempunyai tebal hujan 2500 - $2700 \mathrm{~mm} / \mathrm{tahun}$. Penggunaan lahan pada daerah rentan banjir ini adalah permukiman, tanah terbuka/instalasi prasarana, dan pertanian lahan kering (kebun campuran). Namun penggunaan lahan yang paling dominan adalah permukiman. Daerah rentan banjir di sub DAS Babura terletak pada kemiringan lereng $0-2 \%$ dengan morfologi dataran. Tekstur tanah pada daerah yang rentan terhadap banjir adalah tanah dengan tekstur agak halus. Daerah yang rentan terhadap kejadian banjir adalah daerah yang berada dihilir sub DAS Babura yaitu meliputi Kecamatan Medan Petisah, Medan Polonia, Medan Selayang, Medan Johor dan Medan Tuntungan.

Daerah yang cukup rentan terhadap banjir meliputi daerah yang paling luas, yaitu $2.123,30 \mathrm{Ha}(43,14 \%)$. Daerah cukup rentan di sub DAS Babura mempunyai curah hujan pada kisaran $2600-2700 \mathrm{~mm} /$ tahun. Daerah ini terletak pada kemiringan lereng $3-7 \%$ dengan morfologi berombak. Penggunaan lahan yang dominan pada daerah ini adalah pertanian lahan kering (kebun campuran). Selain itu, terdapat juga permukiman, dan kebun campuran yang diselingi dengan semak. Daerah yang cukup 
rentan banjir ini mencakup Kecamatan Namorambe yang masuk dalam system sub DAS Babura, dan sebagian dari Kecamatan Pancurbatu.

Daerah tidak rentan di sub DAS Babura mencakup sebagian wilayah DAS yang terletak di hulu sungai dengan luas $781,98 \mathrm{Ha}(15,98 \%)$. Curah hujan yang jatuh sebesar $2500-2600$ $\mathrm{mm} /$ tahun. Penggunaan lahan pada hulu sungai ini di dominasi oleh kebun campuran yang diselingi oleh semak-semak dan sedikit ditemui adanya tegalan. Kemiringan lereng pada daerah yang tidak rentan banjir ini sebagian besar adalah $8-13 \%$ dengan morfologi bergelombang dan beberapa tempat mempunyai kemiringan lereng $3-7 \%$ (berombak) dengan tekstur tanah yang ada pada daerah ini adalah tekstur sedang. Cakupan wilayahnya meliputi Kecamatan Sibolangit dan Kecamatan Pancurbatu.

\section{Karakteristik Parameter Kerentanan Banjir}

Parameter-parameter yang digunakan dalam menganalisis kerentanan banjir di sub DAS Babura adalah curah hujan, penggunaan lahan, kemiringan lereng, dan tekstur tanah. Curah hujan merupakan faktor utama dalam menganalisis kerentanan banjir dimana curah hujan adalah input utama untuk terjadinya suatu kejadian banjir. Apabila tidak terdapat hujan yang jatuh di permukaan bumi maka tidak akan terjadi banjir di suatu wilayah. Tebal hujan yang tinggi yang turun pada DAS lebih memungkinkan menjadi penyebab terjadinya banjir daripada tebal hujan yang rendah. Hal ini disebabkan oleh hujan dengan ketebalan tinggi akan memberikan sumbangan debit air lebih besar sehingga apabila daya tampung sungai terlampaui akan menyebabkan terjadinya banjir. Dalam penentuan kerentanan banjir di sub DAS Babura, distribusi curah hujan dibagi menjadi lima kelas, yaitu <2000 mm, $2000-2500 \mathrm{~mm},>2500-3000 \mathrm{~mm}$, $>3000-3500 \mathrm{~mm}$, dan > $3500 \mathrm{~mm}$. Sebaran curah hujan tertinggi terjadi di stasiun Tuntungan dengan kisaran $>2700 \mathrm{~mm}$. Semakin ke arah utara, selatan dan timur curah hujan yang terjadi semakin kecil pada kisaran $>2500-2700 \mathrm{~mm}$.

Penggunaan lahan merupakan parameter lain yang digunakan dalam penentuan kerentanan banjir di sub DAS Babura. Penggunaan lahan adalah parameter yang mudah berubah karena adanya pengaruh intervensi manusia pada lahan sehingga penggunaan lahan menjadi faktor penting kedua setelah curah hujan dalam mempengaruhi kerentanan banjir pada suatu wilayah. Perubahan penggunaan lahan akan cenderung meningkatkan koefisien aliran pada suatu wilayah sehingga dapat menyebabkan kemungkinan besar untuk terjadinya suatu kejadian banjir. Sub DAS Babura terdiri dari beberapa jenis penggunaan lahan, yaitu 
permukiman, tanah terbuka/instalasi prasarana, tegalan, pertanian lahan kering, dan pertanian lahan kering dengan semak. Masingmasing penggunaan lahan akan memberikan dampak pada kejadian banjir yang berbeda.

Tanah terbuka/instalasi prasarana akan memberikan nilai koefisien aliran yang lebih besar dibandingkan dengan penggunaan lahan yang lain sehingga menyebabkan kemungkinan terjadinya suatu kejadian banjir lebih besar. Tanah terbuka/instalasi prasarana ini merupakan kawasan bandara Polonia Medan dengan luas 186,46 Ha (3,79\%) yang terletak di hilir sungai Babura yaitu di Kecamatan Medan Polonia. Selain tanah terbuka, hilir Sungai Babura di dominasi oleh permukiman penduduk yang relatif padat yang meliputi, sebagian Kecamatan Medan Petisah, Medan Sunggal, Medan Selayang dan Medan Johor. Di daerah tengah sub DAS Babura didominasi oleh penggunaan lahan berupa pertanian lahan kering (kebun campuran) yang meliputi Kecamatan Medan Tuntungan, dan Kecamatan Namorambe. Di bagian hulu DAS, penggunaan lahan di dominasi oleh Pertanian lahan kering (kebun campuran) diselingi dengan semak-semak. Sub DAS Babura bagian hulu ini meliputi Kecamatan Pancur batu dan Kecamatan Sibolangit Kabupaten Deli Serdang. Penggunaan lahan di sub DAS Babura.

Kemiringan lereng secara tidak langsung berpengaruh terhadap besar kecilnya suatu kejadian banjir. Kemiringan lereng yang besar akan menyebabkan air hujan yang jatuh tidak akan menjadi sebuah genangan tetapi akan diteruskan ke daerah yang lebih rendah. Semakin besar lereng maka semakin cepat air hujan jatuh akan dibawa ke daerah yang terletak di bawahnya (hilir). Sehingga pada daerah hilir sungai yang mempunyai kemiringan lereng yang lebih kecil akan terjadi akumulasi air dan kemungkinan akan terjadi penggenangan. Kemiringan lereng di sub DAS Babura dibagi menjadi tiga kelas, yaitu:

\begin{tabular}{|r|l|l|r|r|}
\hline No & $\begin{array}{c}\text { Kemiringan } \\
\text { Lereng }\end{array}$ & Morfologi & Luas (Ha) & \multicolumn{1}{c|}{$\begin{array}{c}\text { Persen } \\
\text { Luas (\%) }\end{array}$} \\
\hline 1 & $0-2 \%$ & Dataran & $3.455,82$ & 70,21 \\
\hline 2 & $3-7 \%$ & Berombak & 977,06 & 19,85 \\
\hline 3 & $8-13 \%$ & Bergelombang & 489,00 & 9,94 \\
\hline \multicolumn{3}{|c|}{ Luas Total } & 4921,88 & 100,00 \\
\hline
\end{tabular}

Sumber : Analisis Peta Kemiringan Lereng, 2012

Sub DAS Babura didominasi oleh kemiringan lereng 0 2\% (datar) sehingga membentuk morfologi dataran dengan beda tinggi $<5$. Daerah dengan morfologi dataran terdapat di daerah 
hilir sampai tengah sungai Babura, yaitu di hampir semua kecamatan yang termasuk dalam sub DAS Babura kecuali Kecamatan Sibolangit. Morfologi dataran banyak dimanfaatkan oleh penduduk sebagai daerah permukiman dan kebun campuran. Sedangkan kemiringan lereng 3-7\% dan $8-13 \%$ mencakup sebagian daerah di Kecamatan Pancurbatu dan Kecamatan Sibolangit yang banyak dimanfaatkan oleh penduduk untuk kebun campuran dan tegalan.

Tekstur tanah terkait dengan ukuran zarah mineral dalam tanah. Secara tidak langsung, tekstur tanah berpengaruh terhadap koefisien aliran yang nantinya akan menyebabkan suatu kejadian banjir. Tekstur tanah kasar (pasir) mempunyai kemampuan mengikat air lebih rendah sehingga air hujan yang jatuh di permukaan tanah akan terinfiltrasi dengan cepat. Berbeda dengan tanah-tanah yang mempunyai tekstur yang halus dimana pada tanah dengan tekstur halus (lempung) sulit untuk meloloskan air kedalam tanah sehingga kemungkinan untuk terjadinya aliran permukaan akan lebih besar di daerah dengan kemiringan lereng terjal sedangkan pada daerah dengan kemiring lereng datar, tekstur halus cenderung akan membentuk sebuah genangan.

Tekstur tanah di sub DAS Babura dibagi menjadi dua kelas, yaitu agak halus dan sedang. Tekstur tanah agak halus terdapat pada daerah hilir sungai dengan jenis tanahnya adalah Dystropepts Kandiudults Tropaquepts dan Eutrandepts. Tekstur tanah sedang terdapat di daerah hulu sungai dengan jenis tanah Dystropepts dan Tropaquepts Dystropepts.

Empat parameter yang digunakan untuk menentukan kerentanan banjir diatas dapat dibagi menjadi dua, yaitu parameter yang dapat berpengaruh secara langsung terhadap banjir yang terjadi dan parameter yang secara tidak langsung dapat mempengaruhi suatu kejadian banjir. Parameter yang berpengaruh secara langsung adalah curah hujan yang jatuh pada sub DAS Babura sedangkan parameter yang secara tidak langsung mempengaruhi kejadian banjir di sub DAS Babura adalah penggunaan lahan, kemiringan lereng dan tekstur tanah. Kemiringan lereng dan tekstur tanah merupakan parameter yang bersifat tidak mudah berubah. Parameter penggunaan lahan merupakan parameter yang mudah berubah (dinamis) karena adanya pengaruh manusia di dalam memanfaatkan lahan yang ada di sub DAS Babura. Manusia cenderung mengubah pola penggunaan lahan yang ada untuk memenuhi kebutuhan akan ruang dimana semakin bertambah manusia maka memberikan dampak pada alih fungsi lahan pada suatu wilayah termasuk di sub DAS Babura. 
Hujan yang jatuh pada suatu wilayah merupakan input utama yang menjadi tenaga untuk terjadinya suatu kejadian banjir. Sedangkan parameter yang lain merupakan penentu proses yang akan terjadi terhadap input curah hujan yang dapat menyebabkan banjir. Dengan kondisi dan karakteristik parameter-parameter banjir yang sama, apabila curah hujan yang jatuh mempunyai intensitas yang berbeda maka tingkat kerentanan terhadap banjir pun akan berbeda pula. Hal ini disebabkan oleh semakin tinggi curah hujan yang jatuh maka akan memberikan pasokan debit yang lebih besar pada saluran-saluran seperti sungai. Apabila sungai tidak dapat lagi menampung besarnya debit aliran yang terjadi maka akan menyebabkan terjadinya banjir.

Berbeda dengan penggunaan lahan, kemiringan lereng dan tekstur tanah dimana ketiga parameter ini berpengaruh terhadap proses yang akan terjadi terhadap input hujan yang jatuh di DAS. Oleh ketiga parameter ini, air hujan yang jatuh akan mengalami beberapa kemungkinan proses yaitu infiltrasi dan atau mengalir menjadi aliran permukaan. Besar kecilnya kapasitas infiltrasi atau air akan mengalir menjadi runoff sangat ditentukan oleh karakteristik masing-masing parameter tadi. Penggunaan lahan dengan banyak vegetasi dengan penggunaan lahan tanpa vegetasi akan memberikan pengaruh yang berbeda terhadap debit aliran yang dihasilkan karena adanya hujan yang dapat digambarkan dengan nilai koefisien aliran. Lahan dengan banyak vegetasi akan memberikan peluang air hujan untuk lebih banyak terinfiltrasi sedangkan lahan dengan sedikit vegetasi atau tanpa vegetasi memberikan banyak peluang untuk air hujan tersebut menjadi runoff.

\section{Strategi Pengelolaan Lingkungan}

Penanggulangan terhadap banjir dapat ditempuh dengan melihat sebenarnya apa yang menjadi penyebab terjadinya banjir. Umumnya, terjadinya banjir disebabkan oleh parameter dari kerentanan banjir yang tidak permanen (dinamis) yaitu penggunaan lahan. Adanya peningkatan kebutuhan akan lahan menyebabkan terjadinya alih fungsi lahan yang cenderung tidak memperhatikan kemampuan dan kesesuaian lahan yang ada. Ketimpangan antara kemampuan lahan dan kesesuaian lahan dengan pemanfaatan lahan yang terjadi menyebabkan berkurangnya produktivitas lahan dan memicu berbagai masalah lingkungan seperti banjir.

Adanya alih fungsi lahan menyebabkan banyak lahan menjadi terbuka tanpa vegetasi. Hal ini menyebabkan air hujan yang jatuh akan menjadi aliran permukaan yang apabila terakumulasi di daerah hilir akan menyebabkan banjir. Di daerah hulu sungai, 
tingkat erosi menjadi tinggi disebabkan oleh air hujan yang jatuh langsung mengenai permukaan tanah sehingga menyebabkan pengelupasan tanah bagian atas. Erosi yang tinggi di daerah hulu menyebabkan sedimen yang dibawa oleh aliran permukaan yang masuk ke saluran-saluran sungai juga menjadi besar sehingga menyebabkan pendangkalan sungai. Pendangkalan sungai menyebabkan daya tampung sungai menjadi berkurang sehingga memungkinkan untuk terjadinya banjir ketika debit sungai bertambah pada waktu musim penghujan. Pendangkalan sungai juga tidak hanya semata-mata disebabkan oleh sedimen hasil erosi tetapi juga pola perilaku masyarakat dalam membuang sampah. Terkadang sungai dijadikan sebagai tempat pembuangan sampah sehingga menyebabkan pendangkalan sungai oleh tumpukan sampah.

Untuk menanggulangi banjir yang disebabkan oleh factor permanen seperti kemiringan lereng dan tekstur dapat ditempuh dengan adanya konservasi secara vegetative terutama di daerah hulu sungai. Secara mekanik, dapat ditempuh dengan membuat teras-teras yang dapat menahan laju air larian (runoff). Upaya menanggulangi banjir yang disebabkan oleh alih fungsi lahan adalah membuat suatu aturan dan menegakkan aturan tersebut guna meminimalisir terjadinya alih fungsi lahan dan taat terhadap rencana tata ruang yang telah dibuat. Pembangunan yang sesuai dengan tata ruang wilayah sangat ditentukan keberhasilannya oleh pemerintah dimana pemerintah merupakan pembuat, pelaksana dan pengawas dalam penerapan rencana tata ruang wilayah.

Dalam pengelolaan DAS harus selalu merujuk pada prinsip-prinsip pengelolaan sumberdaya lahan, air keanekaragaman hayati (hutan), dan sumberdaya manusia. Kegiatan pengelolaan, meliputi: perencanaan, penataan, penetapan, pemanfaatan, pelestarian, dan pemantauan (7P). Pola pengelolaan pada masa dahulu cenderung partial, topdown dan project oriented, sehingga dalam era otonomi daerah ini terdapat perubahan paradigma pembangunan, sehingga pengelolaan DAS semestinya dilakukan secara terpadu, bottom up, programme oriented dan menerapkan pendekatan partisipasi masyarakat dengan mengutamakan ekonomi kerakyatan. Untuk mengatasi permasalahan-permasalahan yang timbul pada lingkungan DAS harus berdasar pada one river and one management, jadi disini permasalahan DAS harus diatasi tanpa melihat batas administrasi namun dilihat secara utuh sebagai satu system yang tidak terikat oleh batas administrasi tersebut dari hulu sampai hilir.

Upaya penting lain adalah terkait dengan system kelembagaan yang ada. Ditinjau dari segi fungsi-fungsinya, system 
kelembagaan dalam pengelolaan lingkungan secara garis besar dapat dipilah menjadi tiga unsur, yaitu : pemerintah, masyarakat dan lembaga swasta. Masyarakat perlu dilibatkan secara langsung dalam pengelolaan lingkungan karena masyarkat lah yang hidup dan tinggal pada daerah tersebut. Masyarakat berperan dalam memanfaatkan lahan yang nantinya akan berdampak pada besarnya nilai koefisien aliran. Masyarakat harus mampu memanfaatkan lahan sesuai dengan kemampuan lahan yang ada. Masyarakat hulu sungai berperan dalam usaha konservasi lahan dimana masyarakat harus diberdayakan agar tidak melakukan tindakan-tindakan yang merusak lingkungan lahan yang dapat mempengaruhi besarnya debit aliran. Ketiga lembaga diharapkan dapat bekerjasama dan melakukan tugas masing-masing sehingga kelestarian lingkungan hidup dapat terwujud.

\section{Kesimpulan}

Dengan mendasarkan pada hasil penelitian dan pembahasan maka dapat diambil kesimpulan sebagai berikut :

Tingkat kerentanan banjir di subDAS Babura dibagi menjadi tiga, yaitu tidak rentan, cukup rentan dan rentan. Daerah tidak rentan di sub DAS Babura mencakup sebagian wilayah DAS yang terletak di hulu sungai. Cakupan wilayahnya meliputi Kecamatan Sibolangit dan Kecamatan Pancurbatu. Daerah rentan banjir di sub DAS Babura adalah daerah yang berada di hilir sub DAS Babura yaitu meliputi Kecamatan Medan Petisah, Medan Polonia, Medan Selayang, Medan Johor dan Medan Tuntungan. Daerah yang cukup rentan terhadap banjir meliputi daerah yang paling luas, terdiri dari Kecamatan Namorambe, dan sebagian Kecamatan Pancurbatu. Parameter-parameter yang digunakan dalam menganalisis kerentanan banjir di sub DAS Babura adalah curah hujan, penggunaan lahan, kemiringan lereng, dan tekstur tanah. Curah hujan merupakan faktor utama dalam menganalisis kerentanan banjir dimana curah hujan adalah input utama untuk terjadinya suatu kejadian banjir. Apabila tidak terdapat hujan yang jatuh di permukaan bumi maka tidak akan terjadi banjir di suatu wilayah. Tebal hujan yang tinggi yang turun pada DAS lebih memungkinkan menjadi penyebab terjadinya banjir daripada tebal hujan yang rendah. Perubahan penggunaan lahan akan cenderung meningkatkan koefisien aliran pada suatu wilayah sehingga dapat menyebabkan kemungkinan besar untuk terjadinya suatu kejadian banjir. Kemiringan lereng secara tidak langsung berpengaruh terhadap besar kecilnya suatu kejadian banjir. Kemiringan lereng yang besar akan menyebabkan air hujan yang jatuh tidak akan menjadi sebuah genangan tetapi akan diteruskan ke daerah yang 
lebih rendah. Semakin besar lereng maka semakin cepat air hujan jatuh akan dibawa ke daerah yang terletak di bawahnya (hilir). Tekstur tanah sangat terkait dengan kemampuan tanah dalam menginfiltrasi air hujan yang jatuh pada permukaan tanah. Tanah tanah dengan tekstur yang halus - agak halus seperti tekstur lempung, dan lempung berdebu, mempunyai kapasitas infiltrasi yang kecil sehingga air hujan yang jatuh akan lebih banyak menjadi aliran permukaan. Apabila aliran permukaan ini terakumulasi di darah yang datar maka akan dapat membentuk genangan banjir.

Daerah-daerah yang rentan terhadap banjir perlu mendapat perhatian dari berbagai pihak untuk dikelola dengan baik. Untuk itu diperlukan strategi pengelolaan lingkungan yang sesuai dengan faktor penyebab terjadinya suatu kejadian banjir. Prinsip pengelolaan lingkungan DAS harus berpegang pada one river and one management yang tidak mengenal batas administrasi. Kegiatan pengelolaan, meliputi: perencanaan, penataan, penetapan, pemanfaatan, pelestarian, dan pemantauan (7P) yang tentu harus melibatkan tiga unsur kelembagaan, yaitu, Pemerintah, masyarakat dan lembaga swasta.

\section{Daftar Pustaka}

Arifaini, dkk, 2008, Kajian Debit Banjir Pada Daerah Aliran Sungai Tulang Bawang Dengan Metode Kinematis Muskingum, Prosiding, Universitas Lampung

Arsyad, S, 1989, Konservasi Tanah dan Air, Penerbit IPB, Bogor

Asdak, C, 1995, Hidrologi dan Pengelolaan Daerah Aliran Sungai, Gadjah Mada University Press, Yogyakarta

Chow, V,T, 1964, Handbook of Applied Hydrology, McGraw-Hill Book Company, New York and London

Davie, Tim, 2008, Fundamentals of Hydrology (second edition), Routledge, New York

Dewan Riset Nasional, 1994, Kebutuhan Riset dan Koordinasi Pengelolaan Sumber Daya Air di Indonesia, Jakarta

Fandeli, Chafid, 2004, Analisis Mengenai Dampak Lingkungan Prinsip Dasar Dalam Pembangunan, Penerbit Liberty, Yogyakarta

Gunawan, T, 1991, Penerapan Teknik Penginderaan Jauh Untuk Menduga Debit Puncak Menggunakan Karakteristik Lingkungan Fisik DAS, Disertasi, Fakultas Pasca Sarjana, Institut Pertanian Bogor 